\title{
Operation of a hospital palliative care service: a fourth-generation evaluation
}

\author{
Atuação de um serviço de cuidados paliativo hospitalar: avaliação de quarta geração
}

El desempeño de un servicio de cuidados paliativos hospitalarios: una evaluación de cuarta generación

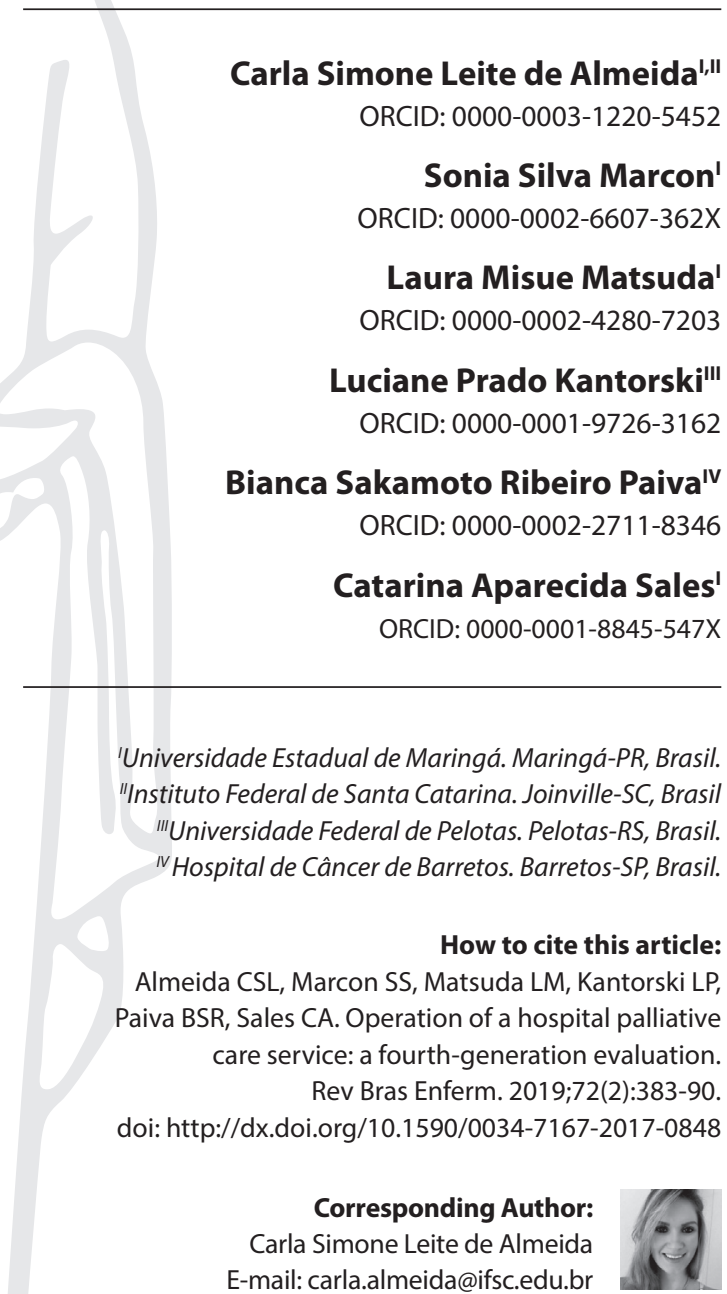

Submission: 10-12-2017

Approval: 18-08-2018

\section{ABSTRACT}

Objective: Qualitatively evaluate the operation of a palliative care service in oncology. Methodology: Qualitative study conducted in a service in southern Brazil based on a fourth generation evaluation. Between September 2014 and June 2015, 460 hours of operation were observed, and 45 semi-structured interviews and five negotiation meetings were conducted; data were analyzed using the constant comparative method. Results: Potential services are: provision of outpatient palliative care, home and inpatient care provided by a multidisciplinary and support team, meeting the patient's biological, psychological, social and spiritual needs. Study limitations: ineffective communication between clinical and surgical oncology and palliative care sectors, lack of specialized training for professionals and in interpersonal relationship issues among team members. Final Consideration: For palliative care progress in the service, some arrangements are required to enhance integrality of care.

Descriptors: Health Services Research; Oncology Service Hospital; Health Services Evaluation; Palliative Care; Hospice Care.

\section{RESUMO}

Objetivo: Avaliar qualitativamente a atuação de um Serviço de Cuidados Paliativos oncológico. Método: Estudo de abordagem qualitativa realizado em um serviço no sul do Brasil, adotando como referencial metodológico a avaliação de quarta geração. Entre setembro de 2014 e junho de 2015 foram realizadas 460 horas de observação, 45 entrevistas semiestruturadas e cinco encontros de negociação e os dados analisados com o método comparativo constante. Resultados: Constituem potencialidades do serviço: oferta de cuidados paliativos na modalidade ambulatorial, domiciliar e internamento, prestada por equipe multidisciplinar e de apoio, o que permite atendimento às necessidades biológicas, psicológicas, sociais e espirituais do pacientefamília. As limitações são: comunicação ineficaz entre setor de oncologia clínica/ cirúrgica e de cuidados paliativos, falta de formação especializada dos profissionais e dificuldade nas relações interpessoais entre os integrantes da equipe. Considerações Finais: Para o avanço dos cuidados paliativos no serviço, fazem-se necessários alguns arranjos que potencializem a integralidade no atendimento.

Descritores: Pesquisa Sobre Serviços de Saúde; Serviço Hospitalar de Oncologia; Avaliação de Serviços de Saúde; Cuidados Paliativos; Cuidados Paliativos na Terminalidade da Vida.

\section{RESUMEN}

Objetivo: Evaluar cualitativamente el desempeño de un Servicio de Cuidados Paliativos oncológico. Método: Estudio de tipo cualitativo, realizado en un servicio en la región Sur de Brasil, adoptando como referencial metodológico la evaluación de cuarta generación. Entre septiembre de 2014 y junio de 2015 se realizaron 460 horas de observación, 45 entrevistas semiestructuradas y 5 encuentros de negociación, y se analizó los datos por el método comparativo constante. Resultados: Se caracteriza el servicio por: ofrecer cuidados paliativos de tipo ambulatorio, domiciliario y de hospitalización, realizado por un personal multidisciplinario y de apoyo, lo que permite asistir a las necesidades biológicas, psicológicas, sociales y espirituales del paciente-familia. Como limitaciones se presentan: la comunicación ineficaz entre los sectores de oncología clínica/quirúrgica y de cuidados paliativos; la falta de formación especializada de los profesionales; y la dificultad en las relaciones interpersonales entre los integrantes del personal. Consideraciones Finales: Para que avancen los cuidados paliativos en el servicio, son necesarios algunos ajustes que favorezca una atención integral.

Descriptores: Investigación en Servicios de Salud; Servicio de Oncología en Hospital; Evaluación de Servicios de Salud; Cuidados Paliativos; Cuidados Paliativos al Final de la Vida. 


\section{INTRODUCTION}

Palliative care aims to minimize suffering and improve the quality of life of patients and families facing issues associated with life-threatening diseases through early identification, proper assessment and treatment of pain and other physical, psychosocial or spiritual problems ${ }^{(1)}$.

The World Health Organization estimates that 20 million people in the world need end-of-life palliative care; $80 \%$ of them live in low- and middle-income countries, $67 \%$ are elderly and $6 \%$ are children ${ }^{(2)}$.

Different bodies ${ }^{(2-5)}$ strongly recommend the provision and insertion of palliative care in health policies; however, a statement issued by the World Health Organization points out that palliative care services (PCS) are still scarce in health institutions, and millions of patients and families who could be benefited otherwise experience their disease process and end of life without dignity, low quality of life and suffering ${ }^{(2)}$. This reality requires emergency mapping of numbers and types of PCS that exist in specific regions of the world to estimate the possible population to be benefited ${ }^{(2)}$.

A study conducted in 2006 and 2011 by the Worldwide Palliative Care Alliance showeed a $9 \%$ increase in palliative activities performed in 234 countries around the world. However, only 20 (8.5\%) of them have an advanced and integrated palliative care system (Australia, Austria, Belgium, Canada, France, Germany, Hong Kong, Iceland, Ireland, Italy, Japan, Norway, Poland, Romania, Singapore, Sweden, Switzerland, Uganda, United Kingdom, United States). Brazil is among the 74 countries (31.6\%) that offer palliative care as an isolated service, that is, the activities have an irregular and unsupported reach, are dependent on donations, have limited availability of morphine, and limited PCS and hospices in relation to the population size ${ }^{(6)}$.

Deficient offer of palliative care in Brazil was also highlighted in two other studies. The study conducted by the Associação Latinoamericana de Cuidados Paliativos - ALCP (Latin American Association for Palliative Care) reported 93 PCSs in the country in 2012 - an insufficient offer, as it represents 0.5 SCP for every $1,000,000$ inhabitants $^{(4)}$. In the 2015 Quality of Death Index, published by the Economist Intelligence Unit, among all 80 countries evaluated, Brazil ranks 48th (score: 33.8 ) and 42nd (score: 42.5) in quality of palliative care and quality of death, respectively ${ }^{(7)}$. These results show the country is far from providing quality palliative care and death with dignity to its patients.

Concerned about this issue, the WHO approved Resolution 31 at its 67th General Assembly, which specifies some actions required in the field of public health, such as: integrate PCSs into the health system structure and financing, with emphasis on primary care; strengthen and expand human resources in this area, including education and professional training; ensure the availability of medication for symptom control, particularly the access to opioids; and develop research policies that identify feasible PCS needs and models for each reality ${ }^{(5)}$.

According to the Public Health Secretariat of the Ministry of Health, for the expansion of palliative care in public health, policies should be formulated and implemented to promote studies that evaluate palliative care needs and identify PCS patterns and models especially for contexts of limited resources ${ }^{(2)}$. It also emphasizes that studies must go beyond PCS quantification. They need to adopt methodologies that allow to diagnose, plan and implement actions, and evaluate the few national experiences in operation and how they take place $\mathrm{e}^{(2,5,8)}$.

Thus, seeking to help fill this gap, this study is based on the following questions: How is a hospital oncology PCS structured and how is it operated? Given the limitations of support, funding, resources and coverage in Brazil today, what is required for the effective operation of PCSs in this reality?

\section{OBJECTIVE}

Qualitatively evaluate the operation of a palliative care service in oncology.

\section{METHODOLOGY}

\section{Ethical aspects}

In the study development, all ethical aspects were observed, according to Resolution 466/2012 of the National Health Council, with approval of the Research Ethics Committee for Studies on Human Beings of Universidade Estadual de Maringá, protocol 665.051, and the Research Ethics Committee of the Oncology Research Center.

To ensure anonymity, the reports of participants were coded as follows: source designation ( $\mathrm{E}$ - interview, $\mathrm{O}$ - observation, $\mathrm{N}$ - Negotiation), followed by P (professional) PF (patient-family), and chronological identification number of $\mathrm{R}$ (Respondent); for example: EPR1, O1, ONP1, ENP1, EPFR1.

\section{Study methodology}

Study based on fourth generation evaluation proposed by Guba and Lincoln ${ }^{(9)}$. This method uses a responsive and constructivist approach, thus proposing the involvement of stakeholders, that is, individuals benefited or impaired by the evaluated object, through an interactive process of formative character that values negotiation $^{(9)}$.

Responsive evaluation is an emerging conception, since the process analyzes the claims, issues and concerns (CICs) of stakeholders, regardless of the value system adopted. Therefore, claim means any claim by the stakeholder in favor of the evaluation object, concern is any unfavorable statement of the stakeholder, and issues are the situations of disagreements that arise in the contexts of claims and concerns ${ }^{(9)}$.

\section{Study type}

This is an exploratory qualitative descriptive case study.

\section{Methodology procedures}

\section{Study site}

The evaluation was conducted at an Oncology PCS in the South region of Brazil, consisting of a Homecare Program (PID) 
hospital unit (16 beds) and an outpatient unit. It has multidisciplinary teams comprised of a physician, a psychologist, a social worker, an occupational therapist, a pharmacist, a nutritionist, a nurse, and a nursing technicians, and/or support of professionals from the fields of dentistry, physical therapy and speech therapy.

\section{Data collection and organization}

Data were collected from September 2014 to June 2015 and involved 480 hours of non-participant observation (recorded in field logs), semi-structured interviews guided by the HermeneuticDialectic Circle (HDC) and five negotiation meetings.

The seven steps proposed by Wetzel ${ }^{(10)}$, translated and adapted from Guba and Lincoln ${ }^{(9)}$ structure, were used to systematize the HDC:

1) Field contact: included the ethical and institutional approval of the study, authorization to enter the PCS, and contact with its stakeholders for their study participation agreement.

2) Organization of evaluation: the evaluation process was explained to stakeholders, seeking to strengthen the link between researcherresearched and understand how respondents construct the meanings that are important for them.

3) Identification of stakeholders: 480 hours of non-participant observation were conducted, which allowed the researcher to recognize the PCS dynamics, its link with the work process and relations, to learn about the social, political and cultural factors, recognizing potentials favored and impaired by the evaluated object (patients, family members and professionals). The creation of two stakeholders was proposed to comprise the HDC (patient-family stakeholder and service professional stakeholder).

4) Development of joint constructions: it involved the application of the HDC through 45 interviews (29 patient-family stakeholders and 16 service professional stakeholders) and five negotiation meetings, as illustrated in Figure 1.

5) Expansion of joint constructions: it consisted in introducing in the interviews questions from practice, literature, observation and/ or documents, aiming to deepen joint constructions ${ }^{(9)}$. Seven issues were introduced in the service professional stakeholder and three in the patient-family stakeholder (Figure 1).

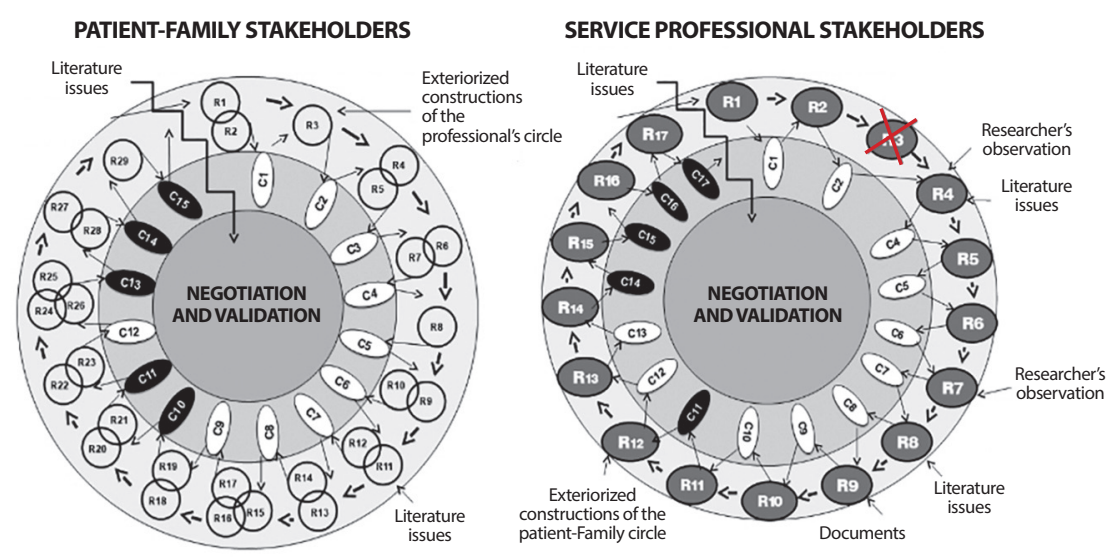

Note: R: respondent, C: Constructions

Source: Developed by the study authors, based on Guba and Lincoln ${ }^{(9)}$.

Figure 1 - Hermeneutic-Dialectic Circles of study stakeholder
6) Development of an agenda for negotiation: the interviews were recorded, transcribed in full, corrected orthographically and submitted to analysis using the constant comparative method ${ }^{(11)}$. The elements that combined with each other in thematic axes were extracted from 60 information units, which were presented at the negotiation meetings.

7) Negotiation meetings: five meetings were held (three with the professional stakeholder and two with the patient-family stakeholder) to present the data obtained in each stakeholder group, seeking a consensus of each information unit generated and subsequent validation. Only validated information in each stakeholder group was included in the final report.

\section{Study stages}

The study participants came from two stakeholder groups: 29 participated in the patient-family stakeholder and 16 in the service professional stakeholder, based on the HDC.

The first participant (Respondent-R1) to be part of the HDC of the service professional stakeholder was selected by a leadership of the PCS. R1 participated in the first HDC interview, which was an open interview guided by four triggering questions: "Tell me about the palliative care service of this institution; Tell me about the work of the palliative care team in this service; Tell me about the challenges you experience in this service; What could help improve the operation of this service?"

At the end of the interview, R1 was asked to select the next participant (R2) to be included in the respective HDC. The answers provided by $\mathrm{R} 1$ were analyzed using the constant comparative method $^{(9,11)}$, determining the initial construction regarding the focus of the evaluation - C1.

In the interview with R2, this participant answered the four triggering questions of the study and then he was asked to give an opinion about $\mathrm{C} 1$, which was analyzed ${ }^{(9,11)}$ and originated a more sophisticated construction named C2. It was explained to R3 after answering the four triggering questions, and so on, until the moment new information no longer expanded prior constructions, as proposed in the reference material ${ }^{(9)}$. Therefore, considering $\mathrm{C} 11$, C14, C15, C16 and C17 no longer generated new CICs, the HDC was concluded with the interview of R17.

It should be noted that R3 from the HDC of the service professional stakeholder, for personal reasons, was removed from the study. Then, $\mathrm{R} 3$ and $\mathrm{C} 3$ were removed from the Hermeneutical Dialectic Circle of the service professional stakeholder, totaling 16 respondents, as illustrated in Figure 1.

The HDC of the patient-family stakeholder was conducted the same way as the HDC of the service professional stakeholder, but the interviews were performed individually and/or collectively. This interview scheme was possible because it the patient-family dyad is present in the care process of the PCS (both are together during the hospitalization period, at doctor's appointments and PID visits). Then, considering senses, 
interests, meanings and issues are jointly constructed by the patient/family member in the PCS, the sharing of experiences, through the collective interview, was believed to provide more $\mathrm{CICs}$. This design agrees with the methodological framework ${ }^{(9)}$, since it ensures flexibility, not supporting one specific discourse, but plural interests and multiple voices.

The first HDC respondent from the patient-family stakeholder was also selected by a leader of the PCS and this interview was guided by the four triggering questions of the study. At the end of each interview, the respondent selected the next respondent to be inserted in the HDC. The guiding questions and constructions from the analysis ${ }^{(11)}$ of the previous interview were introduced to this new respondent, as illustrated in Figure 1. This Hermeneutical Dialectical Circle was concluded with the interview of R29, as C10, C11, C13, C14, and C15 constructions did not generate new $\mathrm{ClCs}$ in their constructions.

\section{Data analysis}

The constant comparative method ${ }^{(11)}$ was used in data analysis based on the fourth-generation evaluation ${ }^{(9)}$. Then, data collection and analysis occurred simultaneously; that is, data analysis was performed during all construction stages and while both HDCs were conducted. The final analysis allowed the identification of five thematic nuclei, 31 information units and two thematic categories: multidisciplinarity and holistic palliative care and integrality of palliative care in the service network.

\section{RESULTS}

The study enrolled 45 subjects selected as potentially favored and impaired by the types of service of oncology PCS (PID). All 31 information units from five thematic nuclei helped identify potentialities, limitations and needs in the reality of the studied PCS, which were systematized through constant comparative method $^{(9,11)}$ in two thematic categories described below.

\section{Multidisciplinarity and holistic palliative care}

For the professionals, multidisciplinarity in bedside visits, meetings with family members/caregivers and in the decision making about patients admitted to the unit were highlighted as differentiations in the care provided.

The physician is rarely alone when he stops by to see the patient. It is already a rule here in the PCS, visits are better in a team [...]. During the visit, we can address and discuss aspects related to that case, that patient and to take some action. (EPR6)

On the other hand, the existence of a multidisciplinary team comprised of from professionals from the fields of psychology, social assistance, occupational therapy, medicine, nursing, pharmacy and nutrition promotes the access to health professionals, creating trust and bonding in professional-patient/family relationships.

I think this type of visit is better, with everyone, because in oncology [Oncology Unit - 1st floor] it is not the same, and that is very bad. For whatever we need, everyone [multidisciplinary team] is there, near us. That's great. (EPFR17)
When I see the whole team entering the room [Inpatient Palliative Unit], they seem like angels coming and God has sent them down here to the Earth [emotional, with crying voice], because they show security and it comforts me. (EPF4)

At the negotiation meeting, the participants highlighted care should cover all dimensions of the human being and that multidisciplinarity is the best way to include patients in palliative care. However, the participants reported limitations in the spiritual dimension of the care provided in the PCS.

Here I feel they consider the body dimensions, not the faith. It is important to be strong in this aspect. (EPFR22)

It lacks spirituality and religiosity. Today, the social worker has to call the churches and ask the priest to provide this support. We do not volunteer with training on these issues of religion/spirituality, the priest that comes here has no training on palliative care. (EPR2)

In addition to the limitation above, in the HDC of service professionals, limitations were reported about the multidisciplinary team work, such as communication issues in the process of professional training and interpersonal relationships, which hinders interdisciplinary actions.

[...] our team is not an interdisciplinary team. The team members share information, but I think they have to communicate more, so one team member does not understand the other one's conduct. (EPR7)

Among professionals of pharmacy, dentistry, speech therapy and physical therapy, only pharmacists participate in multidisciplinary meetings, and I see that this non-participation creates a distance between these professionals, because I feel the professional providing on-demand care (support team) does not have the profile for palliative care, which is expected of a multidisciplinary palliative team. (EPR2)

Making an interdisciplinary team is the biggest challenge. [...] I realize there is a lot of gossip and fight in the team. (EPR12)

Regarding the limitations listed above, at the negotiation meeting both groups agreed that a spiritual assistant is required in the team. The group of professionals agreed that dentists, physical therapists and speech therapists should effectively be part of the multidisciplinary palliative team, not only acting as a supporting professional, offering in-person assistance 24 hours a day. Likewise, they emphasized the PCS should develop strategies that favor continuous interdisciplinary work with trained professionals.

\section{Integrality of palliative care in the service network}

Study participants consider that the PCS is, in theory, a complete service, despite not offering hospice care.

It is a complete service that covers most spheres of palliative care, since we have outpatient clinic, homecare, acute care unit [hospitalization] and possibility of expert opinion [support team]. I consider it a complete service, but it misses a Hospice unit, a hospitality style category, for long stay of patients, which 
offers conditions for a not so sudden dying process that occurs in a hospitality unit, not in a hospital unit. (EPR10)

However, they consider that the type of relationship/communication between the PCS and the clinical/surgical oncology sector of the institution impairs the quality and integrality of palliative care that is offered. They believe that the lack of understanding of palliative philosophy by most clinical/surgical oncology professionals and simultaneous non- adoption of palliative and curative treatment result in late transition of patients to the PCS, creating barriers to care based on palliative principles.

The problem is lack of awareness. I think a better relationship is required between the palliative care team and the clinical/surgical oncology team. It's a battle of egos. (EPR5)

We [the patient's family] had to search palliative care. I think the physician [oncologist], when he saw there was nothing else to do with my mother [the patient] and if he really cared about her, he should have referred her to the palliative service, instead of leaving her there [inpatient oncology unit], suffering. (EPFR2)

The biggest challenge is related to oncology colleagues. We see it when the patient is transferred from there to our service without the patient knowing the reason for such transfer. It is a shock to the patient and family, causing frustrations and false expectations of healing [...]. I believe most oncology employees don't even know that we offer palliative support. It's very difficult for you to have to talk things with professionals who have no idea what you're talking about. (EPR6)

Late transfer of the patient to PCS limits the team's actions with the patient and family; therefore, it impairs all care of the dying process and death with dignity and acceptance.

[...] Oncology does not accept the end of the treatment to refer the patient to palliative care, they take too long to transfer the patient. They want to try all kinds of treatment and when they transfer, it is too late, and palliative care will no longer work out, because the patient's life is at the end. (EPR5)

I realize families who are in the process of mourning, who have received longer follow-up in palliative care, are able to better handle and close this issue of mourning, not generating depression or other disorder. [...] We talked about a project to create a post-death group, but our demand is high, with a small number of professionals. (EPR14)

The respondents believe full integrality of palliative care in oncology depends on the existence of a Hospice unit and physical conditions that allow body preparation and mourning of the family in the post-death period.

Today, we use inpatient clinic for patients who stay months in hospital in an attempt to offer hospice care. A specific area is required, because it is difficult to see both types of patients in the inpatient clinic. The family and the patient question it and compare the conducts adopted in the service. (EPR13)

I think there should be a proper place to prepare the body, outside the hospitalization floor, see, if we have two deaths today we cannot prepare two bodies at the same time, and the family members don't feel comfortable with the place, they get worried. (EPR4)

At the negotiation meeting of the service professionals, they agreed palliative care in the PCS requires a new structure of training, communication and dissemination of palliative care in the institution, so that they can be offered at the right moment, avoiding frustration and suffering due to sudden transfer from clinical/surgical oncology to the PCS.

\section{DISCUSSION}

In 2002 , the $\mathrm{WHO}^{(12)}$ published its latest definition of palliative care and established nine guiding principles, highlighting multidisciplinary approach as a critical element for full well-being of patients and family members ${ }^{(13)}$.

Then, an in-hospital palliative care team consisting of medicine, nursing, physical therapy, social work, psychology and chaplaincy ${ }^{(4)}$ members is a minimum requirement for the provision of holistic palliative care covering psycho-emotional, social, spiritual and biological ${ }^{(14)}$ aspects, becoming mandatory to any hospital linked with the National Health Service ${ }^{(15)}$.

Although the PCS staff exceeds the level established by the Ministry of Health ${ }^{(15)}$, some limitations and needs still have to be resolved in the service, such as the provision of multidisciplinary team support 24 hours a day and inclusion of a spiritual representative in the team. These measures will help the service to meet the needs of the patient/family in all their human dimensions ${ }^{(12)}$, observing the principle for the integration of psychological and spiritual aspects ${ }^{(16)}$.

Patient-family stakeholders, as identified in another study ${ }^{(17)}$, reported patients with no possibility of cure and their families feel the need to discuss issues related to end-of-life, transcendence and spiritual suffering with the physician and the care team. However, the literature reports few PCSs in Brazil and worldwide are able to offer such care to patients and families ${ }^{(7,18)}$. It may be due to the lack of preparation of professionals ${ }^{(4,16)}$ to talk about religiosity and spirituality with patients and their relatives ${ }^{(17-18)}$ and/or lack of specialized professionals linked with the multidisciplinary palliative team ${ }^{(4,19)}$. This condition of undervaluing such an important aspect of human life, as reported in another study ${ }^{(14)}$, is a barrier to providing holistic palliative care.

Spiritual follow-up for professionals and especially for patients and families, and since the start of the disease, through active chaplaincy or pastoral programs, increases the probability of patients to receive early palliative care and improve their quality of life in the pre-death period $^{(17,20)}$, reduces the number of in-hospital deaths, increases admissions in long-stay services ${ }^{(19)}$, and improves communication and care provided ${ }^{(20)}$. Thus, the insertion of spiritual support in the studied PCS can help resolve limitations related to the integration of holistic care, improve the communication process, the interdisciplinary work, the quality of patient-family care during the process of death, dying and grieving, and the integrality of the care provided.

The multidisciplinary approach in palliative care should be based on interdisciplinarity ${ }^{(21)}$ involving authentic communication, respect for other professionals and their knowledge, and acceptance of differences ${ }^{(22)}$. Therefore, cooperation, exchanges between disciplines, articulation of knowledge and actions, 
horizontal relations, participation in decision-making ${ }^{(22)}$ and specific professional training ${ }^{(16,23)}$ are required.

Non-sharing of knowledge and disarticulation of specialized work among the team members can be considered as absence of team work ${ }^{(21)}$. The reality is fragile in the evaluated PCS, due to ineffective communication with the clinical/surgical oncology sector, lack of sharing/understanding of the actions and knowledge between the different professional categories that comprise the multidisciplinary team, and lack of specific training on how to handle bad news. Such fragilities limit integrality of palliative care offered by the service, since a successful treatment, with improved quality of life and relieved suffering, depends directly on communication, an essential skill in the professional-patient relationship ${ }^{(24)}$ and in interaction between professionals, allowing vertical support, articulation of knowledge and actions between the multidisciplinary teams from different sectors, and assured integrality ${ }^{(22)}$.

One of the major challenges faced by health professionals, mainly physicians, is the recognition of a "palliative care patient"(8). Professional training in health prioritizes saving lives, seeking health, vitality, hope, and not dealing with death. It turns communication of bad news, related to the process of dying and death, into a difficult assignment of health professionals ${ }^{(16,24)}$. In the clinical/surgical oncology sector, managing bad news involves the challenges of discussing diagnosis, disease progression, prognosis and transfer to palliative care. The ineffective communication process, according to study participants, limits the early start and integrality of palliative care.

If, on the one hand, the start of palliative care should be as early as possible; on the other hand, its end cannot be limited to the patient's death, as observed in the assessed PCS. The family as a unit of care must receive support from the service throughout the patient follow-up, which should continue after the patient's death, during the mourning period ${ }^{(25)}$.

The palliative principle of "offering a support system to assist family members in coping with grief"(16) should be offered by the PCS to the family, in areas that enable their participation at the moment of death, with support during the period when bureaucratic issues are resolved, such as the funeral service ${ }^{(22)}$, rites of passage, when important for the family ${ }^{(8)}$, and follow-up in the mourning process ${ }^{(16)}$.

Postmortem body preparation was recognized as a process that needs to be restructured in the hospitalization unit of the evaluated PCS. For the participants, arrangements are required in the room for body preparation and cooling, which would allow the family to perform rites of passage with more privacy. It is a factor of protection and prevention of family mourning, considering that, when a rite of passage cannot be performed, they family members find it difficult to accept death and restructure the family ${ }^{(8)}$.

For the PCS evaluated, being integrated into a hospital specialized in oncology ensures the provision of emergency, outpatient, hospital and home care. However, the verticality of its support is limited, as observed in other PCSs ${ }^{(26,27)}$, due to the late transition of patients from the clinical/surgical oncology sector. Such delay and the absence of a model of long-stay hospitalization (hospice) and mourning support do not allow an effective handling of the process of dying and death.

Although a 9\% increase was observed in the number of hospice worldwide from 2006 to 2013 as a result of the incorporation of this service in $58 \%$ of the countries ${ }^{(6)}$, its limitation in the PCSs is still an issue to be resolved in all countries ${ }^{(3-4,6)}$.

The increase in hospice in the world is possibly due to studies showing the benefits of this type of service. For example, Medicare ${ }^{(28)}$ analyzed two groups of patients with end-stage cancer and concluded that those receiving hospice care had significantly lower rates of hospitalization, intensive care unit admission, and end-of-life invasive procedures, resulting in significantly lower health care expenses in the last year of life. Results like these can be used as a strategy to support the implementation of these services, especially in countries with limited financial resources.

Finally, it should be noted that integrality of palliative care can be achieved through a multidisciplinary and multisectoral approach, adapted to the cultural, social and economic context of each reality, and integration into existing health systems, with emphasis on primary, hospital and home health care ${ }^{(2)}$, that is, by incorporating and ensuring interrelation of palliative care in every context with all health sectors: emergency services, intensive care units (ICUs), inpatient and outpatient clinics, homecare and hospice, also known as hospitality, nursing homes or long-stay institutions.

\section{Study limitations}

The results of this study are limited to the reality of an oncology PCS, not accepting its generalization, but it allowed to diagnose, evaluate and explore one of the few national experiences related to palliative care in Brazil.

\section{Contribution to nursing, health and public policies}

The fourth-generation evaluation allowed a voice to those who experience on a daily basis the impossibility of a treatment for cancer and those who provide care to these patients in their end of life, highlighting the type of evaluation approach as an effective methodological process for evaluations in palliative care services and other health settings.

The results obtained with this study contribute to public health areas since they meet the demands approved at the 67th General Assembly of WHO by Resolution 31 and the Secretariat of Public Health, directly contributing to research policies that seek to identify PCS needs and models for each reality in the country.

\section{FINAL CONSIDERATIONS}

This evaluation, based on the method of fourth-generation evaluation, helped recognize the potentialities, limitations and needs experienced in the daily life of an oncology PCS in its local reality. The study results support the decision-making process and helps fill the gap of qualitative evaluation studies in health as a whole.

The PCS analyzed in this study presents potentialities such as the provision of palliative care in outpatient, home and hospitalization categories, with a multidisciplinary team comprised of professionals who exceed the minimum number set by the Ministry of Health, who work eight hours a day, and a support team to fulfill biological, psychological, social and spiritual needs of patients and family members.

The limitations include ineffective communication between the clinical/surgical oncology sector and the palliative care, lack 
of specialized training of professionals and difficult interpersonal relationships among the team members.

A number of requirements must be fulfilled to promote progress of palliative care in the studied service and ensure care integrality.
Some suggestions are: early start of palliative support during curative treatment, incorporation of spiritual care by trained professionals, creation of hospice care, and incorporation of care into the postmortem body preparation, with family participation and mourning support.

\section{REFERENCES}

1. World Health Organization-WHO. Definition of Palliative Care [Internet]. 2012[cited 2017 Sep 10]. Available from: http://www.who.int/ cancer/palliative/definition/en

2. World Health Organization. Strengthening of palliative care as a component of integrated treatment throughout the life course. J Pain Palliat Care Pharmacother. 2014 Jun;28(2):130-4. doi: 10.3109/15360288.2014.911801.

3. Centeno C, Lynch T, Garralda E, Carrasco JM, Guillen-Grima F, Clark D. Coverage and development of specialist palliative care services across the World Health Organization European Region (2005-2012): Results from a European Association for Palliative Care Task Force survey of 53 Countries. Palliative Med[Internet]. 2016 [cited 2016 Mar 10];30(4):351-62. Available from: https://www.ncbi.nlm.nih.gov/pmc/articles/ PMC4800456/pdf/10.1177_0269216315598671.pdf

4. Pastrana T, Lima L, Pons JJ, Centeno C. Atlas de Cuidados Paliativos en Latinoamérica. Houston: IAHPC Press; 2013.

5. Marcucci FCl, Cabrera MAS, Rosenberg JP, Yates P. Integration of palliative care in the health system: the Australian model and learning for its implementation in Brazil. Rev Saúde Pública Paraná[Internet]. 2016 [cited 2017 Sep 10];17(1): 56-64. Available from: http://www.uel.br/ revistas/uel/index.php/espacoparasaude/article/view/23900/pdf

6. Lynch T, Clark D, Connor S. Mapping levels of palliative care development: a global update. J Pain Symptom Manag[Internet]. 2013[cited 2017 Sep 10];45(6):1094-106. Available from: http://www.jpsmjournal.com/article/S0885-3924(12)00334-X/pdf

7. Economist Intelligence Unit. The 2015 Quality of Death Index: Ranking palliative care across the world. Lien Foundation; 2015.

8. Silva, MM, Büscher A, Moreira MC, Duarte SCM. Visiting hospices in Germany and United Kingdom from the perspective of palliative care. Esc Anna Nery[Internet]. 2015[cited 2017 Sep 10];19(2):369-75. Available from: http://www.scielo.br/pdf/ean/v19n2/en_1414-8145ean-19-02-0369.pdf

9. Guba EG, Lincoln YS. Avaliação de quarta geração. Campinas: Unicamp; 2011.

10. Wetzel C. Avaliação de serviço em saúde mental: a construção de um processo participativo. [Tese]. Universidade de São Paulo, Programa Escola de Enfermagem de Ribeirão Preto; 2005. 291p.

11. Angelis S. El método comparativo constante. Educa Red; 2005. Portuguese.

12. World Health Organization-WHO. National Cancer Control Programmes: policies and managerial guidelines world. Geneva: World Health Organization; 2002.

13. Garcia JBS, Rodrigues RF, Lima SF. Structuring a palliative care service in Brazil: experience report. Rev Bras Anestesiol[Internet]. 2014[cited 2016 Oct 11];64(4):286-91. Available from: http://www.scielo.br/pdf/rba/v64n4/0034-7094-rba-64-04-00286.pdf

14. Arrieira ICO, Thofehrn MB, Porto AR, Palma JS. [Spirituality in the interdisciplinary team that works with palliative care to cancer patients]. Cienc Cuid Saude[Internet]. 2011 [cited 2017 Oct 01];10(2):314-21. Available from: http://www.periodicos.uem.br/ojs/index.php/ CiencCuidSaude/article/view/15689/pdf Portuguese.

15. Ministério da Saúde (BR). Despacho no 10429/2014. [Internet]. 2014 [cited 2017 Sep 25]. Available from: http://www.sg.min-saude.pt/NR/ rdonlyres/A110CE46-A607-4BD1-AB82-BE86B31314C3/39100/Despacho10429_2014_11deAgosto.pdf

16. Carvalho RT. Manual de Cuidados Paliativos. Rio de Janeiro: Academia Nacional de Cuidados Paliativos; 2012.

17. Cervelin AF, Kruse MHL. Spirituality and religiosity in palliative care: learning to govern. Esc Anna Nery[Internet]. 2014[cited 2015 Oct 07];18(1):136-42. Available from: http://www.scielo.br/pdf/ean/v18n1/en_1414-8145-ean-18-01-0136.pdf

18. Sato $K$, Inoue $Y$, Umeda M, Ishigamori I, Igarashi A, Togashi S, et al. A japanese region-wide survey of the knowledge, difficulties and selfreported palliative care practices among nurses. Japan J Clin Oncol[Internet]. 2014[cited 25 Sep 2017];44(8):718-28. Available from: http:// citeseerx.ist.psu.edu/viewdoc/download?doi=10.1.1.1017.9330\&rep=rep1\&type=pdf

19. Gobatto CA, Araujo TCCF. Religiosity and spirituality in oncology: Health Professionals' conceptions. Psicol USP[Internet]. 2013 [cited 2015 Oct 11];24(1):11-34. Available from: http://www.scielo.br/pdf/pusp/v24n1/v24n1a02.pdf

20. Francisco DP, Costa ICP, Andrade CG, Santos KFO, Brito FM, Costa SFG. Contributions of the chaplaincy service to the care of Terminal patients. Texto Contexto Enferm[Internet]. 2015[cited 2017 Oct 20];24(1):212-9. Available from: http://www.scielo.br/pdf/tce/v24n1/ pt_0104-0707-tce-24-01-00212.pdf

21. Silveira MH, Ciampone MHT, Gutierrez BAO. Perception of multiprofessional staff of palliative care. Rev Bras Geriatr Gerontol[Internet]. 2014[cited 2015 Oct 11];17(1):7-16. Available from: http://www.scielo.br/pdf/rbgg/v17n1/1809-9823-rbgg-17-01-00007.pdf

22. Cloyes KG, Rosenkranz SJ, Berry PH, Supiano KP, Routt M, Shannon-Dorcy K, et al. Essential elements of an effective and sustainable prison hospice program. Am J Hosp Palliat Care[Internet]. 2016[cited 2017 Oct 29];33(4):390-402. Available from: https://www.ncbi.nlm.nih.gov/ 
pmc/articles/PMC4558405/pdf/nihms-676309.pdf

23. Cardoso DH, Muniz RM, Schwartz E, Arrieira ICO. Hospice care in a hospital setting: the experience of a multidisciplinary team. Texto Contexto Enferm[Internet]. 2013[cited 2016 Dec 06];22(4):1134-41. Available from: http://www.scielo.br/pdf/tce/v22n4/en_32.pdf

24. Borges MM, Santos Jr R. Communication in the Transition to Palliative Care: review article. Rev Bras Educ Médica[Internet]. 2014 [cited 2015 Oct 14];38(2):275-82. Available from: http://www.scielo.br/pdf/rbem/v38n2/a15v38n2.pdf

25. Braz MS, Franco MHP. Palliative care professionals and their contribution to the prevention of complicated grief. Psicol: Ciênc Prof[Internet]. 2017[cited 2017 Oct 1];37(1):90-105. Available from: http://www.scielo.br/pdf/pcp/v37n1/1982-3703-pcp-37-1-0090.pdf

26. Obermeyer Z, Makar M, Abujaber S, Dominici F, Block S, Cutler DM. Association between the Medicare Hospice Benefit and health care utilization and costs for patients with poor-prognosis cancer. JAMA [Internet]. 2014 [cited 2017 Sep 02];312(18):1888-96. Available from: https://www.ncbi.nlm.nih.gov/pmc/articles/PMC4274169/pdf/nihms647681.pdf

27. Jünger S, Pastrana T, Pestinger M, Kern M, Zernikow B, Radbruch L. Barriers and needs in paediatric palliative home care in Germany: a qualitative interview study with professional experts. BMC Palliative Care[Internet]. 2010[cited 2015 Oct 14];9:10. Available from: https:// bmcpalliatcare.biomedcentral.com/track/pdf/10.1186/1472-684X-9-10?site=bmcpalliatcare.biomedcentral.com 